Trinity University

Digital Commons @ Trinity

Health Care Administration Faculty Research

Health Care Administration

Fall 1992

\title{
Labor Earnings, Discrimination, and the Racial Composition of Jobs
}

Barry T. Hirsch

Edward J. Schumacher

Trinity University, eschumac@trinity.edu

Follow this and additional works at: https://digitalcommons.trinity.edu/hca_faculty

Part of the Medicine and Health Sciences Commons

\section{Repository Citation}

Hirsch, B.T. \& Schumacher, E.J. (1992). Labor earnings, discrimination, and the racial composition of jobs. Journal of Human Resources, 27(4), 602-628. doi: 10.2307/146077

This Article is brought to you for free and open access by the Health Care Administration at Digital Commons @ Trinity. It has been accepted for inclusion in Health Care Administration Faculty Research by an authorized administrator of Digital Commons @ Trinity. For more information, please contact jcostanz@trinity.edu. 


\title{
Labor Earnings, Discrimination, and the Racial Composition of Jobs
}

\author{
Barry T. Hirsch \\ Edward J. Schumacher
}

\begin{abstract}
A B S T R A C T
This paper examines the effect of the racial composition of labor markets on wage rates and the racial wage gap. The wage rates of white as well as black workers are significantly lower in industry-occupation-regional groups with high densities of black workers, while the racial wage gap does not vary systematically with respect to racial density. Interpretation of racial gap estimates can be sensitive to inclusion of a racial density variable, particularly in sparse specifications. An explanation for the wagedensity relationship cannot be established, but results are most consistent with a quality sorting explanation and, to a lesser extent, the crowding hypothesis.
\end{abstract}

\section{Introduction}

There has been extensive study of racial wage differentials and labor market discrimination, yet scant attention has been given to how wage rates vary with the racial composition of jobs. This paper explores the extent to which the wages of black and white workers, and the racial wage gap, differ with respect to the proportion of black workers in a labor market. Such a study has value for at least three reasons. First,

\footnotetext{
Barry T. Hirsch is a professor of economics and Edward J. Schumacher is a graduate student at Florida State University in Tallahassee. They appreciate helpful comments from Mark Berger, William R. Johnson, Kevin Lang, David Macpherson, James Ragan, Andrew Weiss, anonymous referees, and discussants at the 1990 American and Southern Economic Association meetings. The data used in this article can be obtained beginning in March 1993 through March 1996 from the authors at the following address: Department of Economics R-128, Florida State University, Tallahassee, FL 32306-2045.
} 
evidence on whether black and white wages vary systematically with racial composition is interesting in its own right. Second, we provide information as to how traditional estimates and interpretation of wage discrimination are affected by consideration of racial composition. Finally, the relationship between black and white wages and the racial composition of jobs facilitates an appraisal of alternative theories of labor market discrimination, thus shedding light on what is a major lacuna in the literature (Cain 1986, p. 709).

Previous evidence on the relationship of wages and the racial composition of labor markets is limited. ${ }^{1}$ The two studies most closely related to ours are Ragan and Tremblay (1988) and Sorensen (1989). Ragan and Tremblay (1988) review the limited literature on employee discrimination and test for it using the National Longitudinal Survey (NLS) youth cohort of workers ages 15-23. The NLS contains information on the presence of an integrated workforce, the race and sex of the immediate supervisor, and the percentage of the immediate workforce of a different race and sex. Ragan and Tremblay conclude that there is evidence of employee discrimination with respect to race, based on the finding of higher wages for whites in integrated work environments. More closely related to evidence presented here, Ragan and Tremblay find that white male and female wages decrease as the percentage of the immediate workforce of a different race increases, while black male wages increase as the percentage not black increases (the former results are not statistically significant; the latter marginly significant). They place little emphasis on these latter results, however.

In a comprehensive study on occupational segregation by sex and race, Sorensen (1989) matches information from the 1980 Census of Population on the racial density of occupations to individual data from the Current Population Survey and the Panel Study of Income Dynamics. She finds that the wages of white males decrease as the racial density of an occupation increases, but finds little systematic relationship between racial density and wages among other demographic groups. Because this relationship is not the focus of the paper, she provides only limited analysis and discussion of these results.

1. Cain (1986) provides a detailed survey and analysis of the theoretical and empirical literature on racial discrimination. Chiswick (1973) uses state data to examine the relationship between racial composition and white earnings dispersion, while Reich (1978) relates white income inequality across labor markets to black-white income ratios. We discovered Sorensen (1989) following completion of an earlier version of this paper. Studies using a methodology similar to ours have examined the impact of the proportion female on the wages of female and male workers, and of union density on the wages of union and nonunion workers. 
In this study, a racial density variable constructed from the 1980 Census of Population is matched with Current Population Survey data to explore the relationship of racial density with black and white wages and estimates of the racial gap. Our study has advantages and disadvantages as compared to the analyses by Ragan and Tremblay and by Sorensen. The racial composition variables available to Ragan and Tremblay from the NLS directly measure the racial makeup in an individual's workplace and, thus, are particularly well designed to test for employee discrimination and to minimize measurement error associated with the matching of aggregate density measures to individual workers. Ragan and Tremblay's analysis is limited because data are available only on young workers ages 15-23 and because sample sizes are relatively small. As will be seen, care must be exercised in generalizing results from a small youth sample to the larger population.

Our analysis and data have much in common with those in Sorensen. We construct a racial composition variable, however, that measures racial density within industry-occupation-region (IOR) cells (say, a machine operator in the textile industry in the South), whereas Sorensen measures density by occupation only. Our measure corresponds more closely to the concept of a labor market, although we are unable to provide as detailed an occupational breakdown. Whereas we find average racial density in IOR groups to be twice as large for black as for white workers, Sorensen (1989, Appendix B, p. 63) finds occupational black density to be only moderately larger for black than for white workers.

In Section II, construction of the dataset is explained and descriptive evidence is provided. In Section III, wage equations estimated separately by racial/gender group provide evidence on the relationship of wages and wage gaps with the racial composition of jobs. Interpretation of results and an appraisal of discrimination models in light of the evidence are provided in Section IV.

\section{Data and Descriptive Evidence on Racial Density and Wages}

Two primary data sources are used in the paper. Individual data on hourly earnings, individual characteristics, job characteristics, and region are obtained from the combined May-June Current Population Surveys (CPS) for 1983, including the pension supplement containing information on individuals' tenure on their current job and on firm and establishment size (similar surveys are available for 1979 and 1988). Our wage equation sample includes all white and black workers between 16 and 64 with positive weekly earnings and hours worked per week and 
complete data for all individual and job characteristics. Workers whose race is designated as "other" are not included in the sample since their numbers are relatively small and this group exhibits substantial heterogeneity.

A racial density variable, $D E N$, measuring the ratio of black to the sum of white and black workers in a labor market, is matched to each worker in the CPS sample. ${ }^{2}$ These data are derived from the 1980 Census of Population and are defined for 14 industry $(I)$ groups cross-classified by 67 occupational $(O)$ groups cross-classified by the four major Census regions $(R)$, for a total of 3,752 IOR cells (U.S. Department of Commerce 1984, Part 1, Section 3, Table 327). Use of the Census of Population guarantees the largest possible sample sizes. A number of the IOR cells are small or empty and have no matching counterparts in the CPS sample. The sample sizes in the matched cells range from a low of 343 to a high of 1,731,779 (six individuals in the CPS matched to IOR cells with between 17 and 172 workers are dropped from our sample). Although guided in large part by data availability and sample size, our designation of a labor market corresponds closely to an economic definition, being defined rather finely along occupational lines and more broadly by industry and region. ${ }^{3}$

Sample sizes for the four demographic groups are 10,776 white males, 811 black males, 9,016 white females, and 963 black females. Mean $D E N$ values (standard deviations) for the four groups are $.083(.071), .168$ (.116), .098 (.078), and .198 (.159), respectively. Table 1 presents mean values of worker characteristics variables for the four racial/gender groups, in total and separately by four $D E N$ categories. It is clear from Table 1 that wages for white and black males decrease markedly with respect to racial density. The wage-density pattern for females is similar, although less clear-cut. Some of this decrease is accounted for by differences in years of schooling, which decrease with respect to $D E N$. On the other hand, experience tends to increase with $D E N$. Because individual characteristics differ with respect to racial composition, regression analysis is necessary to estimate the extent to which wage differentials associated with $D E N$ can and cannot be accounted for by differences in measurable characteristics.

2. DEN approximates but does not equal the proportion of black workers in a labor market, since nonwhite, nonblacks are excluded. The same $D E N$ values are matched to males and females working in identical $I O R$ groups.

3. A labor market typically is thought to be defined on the basis of skill types (occupation) within geographic areas (regions) across which mobility is limited. For evidence that systematic long-run wage differentials also exist across industries, see, among others, Dickens and Katz (1987) and Krueger and Summers (1987). 
Table 1

Means of Variables by Demographic Group and Racial Density Category

\begin{tabular}{|c|c|c|c|c|c|}
\hline & $0 \leq D E N \leq .05$ & $.05<D E N \leq .08$ & $.08<D E N \leq .13$ & $D E N>.13$ & All \\
\hline \multicolumn{6}{|l|}{ White males } \\
\hline$D E N$ & 0.03 & 0.06 & 0.10 & 0.20 & 0.08 \\
\hline Hourly earnings & 10.61 & 9.77 & 8.83 & 7.59 & 9.52 \\
\hline Schooling & 13.56 & 13.15 & 12.24 & 12.05 & 12.94 \\
\hline Experience & 17.72 & 18.80 & 19.81 & 18.45 & 18.52 \\
\hline Tenure & 7.40 & 8.56 & 8.74 & 6.70 & 7.82 \\
\hline Union & 0.19 & 0.33 & 0.38 & 0.31 & 0.28 \\
\hline Married & 0.69 & 0.69 & 0.68 & 0.64 & 0.68 \\
\hline Fulltime & 0.92 & 0.91 & 0.93 & 0.86 & 0.91 \\
\hline Large SMSA & 0.38 & 0.37 & 0.33 & 0.28 & 0.35 \\
\hline $\mathrm{n}$ & 4,106 & 2,679 & 2,073 & 1,918 & 10,776 \\
\hline \multicolumn{6}{|l|}{ Black males } \\
\hline$D E N$ & 0.04 & 0.06 & 0.10 & 0.25 & 0.17 \\
\hline Hourly earnings & 10.40 & 9.18 & 7.89 & 6.44 & 7.55 \\
\hline Schooling & 13.65 & 12.74 & 11.42 & 11.07 & 11.64 \\
\hline Experience & 18.57 & 20.25 & 21.47 & 22.25 & 21.43 \\
\hline Tenure & 7.08 & 8.16 & 8.34 & 7.91 & 7.96 \\
\hline Union & 0.36 & 0.38 & 0.45 & 0.39 & 0.40 \\
\hline Married & 0.58 & 0.57 & 0.58 & 0.55 & 0.56 \\
\hline Fulltime & 0.91 & 0.90 & 0.87 & 0.88 & 0.88 \\
\hline Large SMSA & 0.61 & 0.70 & 0.53 & 0.41 & 0.50 \\
\hline $\mathrm{n}$ & 77 & 122 & 179 & 433 & 811 \\
\hline
\end{tabular}




\begin{tabular}{|c|c|c|c|c|c|}
\hline \multicolumn{6}{|l|}{ White females } \\
\hline$D E N$ & 0.04 & 0.06 & 0.10 & 0.21 & 0.10 \\
\hline Hourly earnings & 6.91 & 6.78 & 6.43 & 6.13 & 6.59 \\
\hline Schooling & 13.24 & 13.34 & 12.59 & 12.28 & 12.89 \\
\hline Experience & 16.88 & 16.88 & 19.07 & 19.48 & 18.00 \\
\hline Tenure & 4.76 & 5.52 & 5.65 & 5.39 & 5.31 \\
\hline Union & 0.13 & 0.21 & 0.21 & 0.22 & 0.19 \\
\hline Married & 0.57 & 0.58 & 0.59 & 0.58 & 0.58 \\
\hline Fulltime & 0.70 & 0.73 & 0.73 & 0.72 & 0.72 \\
\hline Large SMSA & 0.38 & 0.38 & 0.33 & 0.26 & 0.34 \\
\hline $\mathrm{n}$ & 2,490 & 2,311 & 2,184 & 2,031 & 9,016 \\
\hline \multicolumn{6}{|l|}{ Black females } \\
\hline$D E N$ & 0.04 & 0.06 & 0.10 & 0.29 & 0.20 \\
\hline Hourly earnings & 6.81 & 7.52 & 6.86 & 5.52 & 6.17 \\
\hline Schooling & 13.05 & 13.68 & 12.51 & 11.73 & 12.26 \\
\hline Experience & 13.90 & 17.12 & 18.49 & 21.89 & 19.82 \\
\hline Tenure & 5.48 & 7.41 & 6.42 & 7.35 & 6.98 \\
\hline Union & 0.26 & 0.41 & 0.31 & 0.28 & 0.30 \\
\hline Married & 0.40 & 0.33 & 0.42 & 0.41 & 0.40 \\
\hline Fulltime & 0.74 & 0.85 & 0.83 & 0.77 & 0.79 \\
\hline Large SMSA & 0.72 & 0.62 & 0.64 & 0.38 & 0.50 \\
\hline $\mathrm{n}$ & 93 & 120 & 199 & 551 & 963 \\
\hline
\end{tabular}

$D E N=$ number of black workers divided by sum of white and black workers in individual's industry-occupation-region (IOR) cell; Hourly earnings = usual weekly earnings divided by usual hours worked per week; Schooling = years of schooling completed; Experience = Age Schooling -5 ; Tenure $=$ years on current job; Union $=1$ if covered by a collective bargaining agreement; Married $=1$ if married, spouse present; Fulltime $=1$ if usual hours worked per week $\geq 35$; and Large SMSA $=1$ if worker resides in CPS-designated SMSA. 


\section{Racial Density, Black and White Earnings, and the Wage Gap}

In order to calculate the racial wage gap and examine the effect of racial composition on earnings, we estimate for each of the four racial/gender groups wage equations taking the following general form:

(1) $\ln W_{i}=\Sigma \beta_{k} X_{i k}+\gamma D E N_{i}+e_{i}$,

where $\ln W_{i}$ is the natural log of hourly earnings for individual $i ; X_{k}$ consists of $X_{1}=1$ and $k-1$ variables measuring personal characteristics, job characteristics, and region; $\beta_{k}$ includes a constant and $k-1$ coefficients corresponding to variables in $X ; D E N$ is the ratio of black to white plus black employment and $\gamma$ is its coefficient; and $e$ is a error term assumed to have zero mean and constant variance. A value of $\gamma<0$ implies that wages for a demographic group decrease with respect to racial density, ceteris paribus, while $\gamma>0$ implies the opposite. Because the relationship between $\ln W$ and $D E N$ is found to be nonlinear, estimates also are provided in which $D E N$ and $D E N S Q$ (density squared) are included.

Included in $X_{k}$ are years of schooling completed; years of potential experience (proxied by age minus schooling minus five) and its square; years of tenure on the current job and its square; and dummies for union status, marital status, full-time status, residence in a large SMSA, firm size (4), industry (13), occupation (5), and region (8). ${ }^{4}$

The logarithmic racial wage gap (calculated separately for males and females) can be decomposed into explained and unexplained portions. Separating that portion of the gap owing to differences in mean $D E N$, and letting superscripts $w$ and $b$ represent white and black, respectively, the decomposition then becomes (dropping subscript $k$ ): ${ }^{5}$

$$
\begin{aligned}
{\overline{\ln W^{w}}}^{w} \overline{\ln W}^{b}= & {\left[\Sigma \beta^{w}\left(\bar{X}^{w}-\bar{X}^{b}\right)\right] } \\
& +\left[\Sigma\left(\beta^{w}-\beta^{b}\right) \bar{X}^{b}+\left(\gamma^{w}-\gamma^{b}\right) \overline{D E N}^{b}\right] \\
& +\left[\gamma^{w}\left(\overline{D E N}^{w}-\overline{D E N}^{b}\right)\right] .
\end{aligned}
$$

Here the bars represent means and the total logarithmic wage gap is decomposed into an explained portion enclosed in the first set of brack-

4. A program designating tape location and creation of all variables from the CPS is available from the authors on request. Dummies measuring establishment size are not included even though both company and establishment size affect wages (Brown and Medoff 1989). Because they are collinear, omission of establishment size (with firm size included) does not bias the remaining coefficients in the model.

5. As is well known, no single decomposition is unique. Nor does the unexplained component necessarily correspond to demand-side labor market discrimination. See Oaxaca (1973) for an early exposition on the measurement of wage differentials. 
ets, an unexplained portion enclosed in the middle set of brackets, and a portion associated with differences in racial composition enclosed in the third set of brackets. The explained portion is that accounted for by differences in measurable characteristics evaluated with white coefficient estimates, the unexplained portion is that owing to differences between the white and black wage structure (coefficients) evaluated at black means, and the portion from racial composition is that owing to differences in mean $D E N$ evaluated at white coefficient values (interpretation of this latter component is provided in Section IV). If $\left(\gamma^{w}-\gamma^{b}\right)>0$ then the unexplained wage gap widens with respect to $D E N$; if negative the gap decreases with $D E N$.

The choice of white coefficients and black means in the decomposition shown in (2) seems appropriate since a nondiscriminatory wage structure should most closely resemble that currently observed for whites. Neumark (1988) shows that the Oaxaca estimators are special cases of a more general decomposition in which the critical issue is the choice of the no-discrimination wage structure $(\beta)$. He suggests an alternative estimator in which $\beta$ is determined by a pooled (white and black) regression. Results presented here will be highly similar to this alternative estimator since the coefficients from white wage equations are very close to those from pooled regressions (any sensitivity to the choice of weights will be noted subsequently).

Equations (1) and (2) can be compared to the more typical Equations $\left(1^{\prime}\right)$ and $\left(2^{\prime}\right)$ below, which do not include the racial composition variable $D E N$ :

$$
\begin{aligned}
& \ln W_{i}=\sum \beta_{k} X_{i k}+e_{i}, \\
& \overline{\ln }^{w}-\overline{\ln W^{b}}=\Sigma \beta^{w}\left(\bar{X}^{w}-\bar{X}^{b}\right)+\Sigma\left(\beta^{w}-\beta^{b}\right) \bar{X}^{b} .
\end{aligned}
$$

Subsequent comparison of (2) with $\left(2^{\prime}\right)$ will indicate the extent to which omission of $D E N$ affects conventional estimates of the racial wage differential. And letting $d$ represent a logarithmic wage differential, the percentage differential can be approximated by $[\exp (d)-1] 100$ (Giles 1982).

Table 2 presents full regression results from Equation (1) for each of the four racial/gender groups. We forgo discussion of the coefficients on variables in $X$, and concentrate attention on the $D E N$ coefficients. These are found to be negative and significant for both white and black males, indicating that wages for both races decrease significantly as the percentage of black workers in a labor market increases (standard errors may be biased downward owing to the matching of grouped to individual data). Wages among white males are estimated to decrease 51.9 percent as we move from an entirely white to an entirely black workplace, while the corresponding figure for black wages is 39.2 percent (calculated by 
Table 2

Regression Results, by Racial/Gender Group

\begin{tabular}{|c|c|c|c|c|}
\hline Variable & $\begin{array}{l}\text { White } \\
\text { Males }\end{array}$ & $\begin{array}{l}\text { Black } \\
\text { Males }\end{array}$ & $\begin{array}{c}\text { White } \\
\text { Females }\end{array}$ & $\begin{array}{c}\text { Black } \\
\text { Females }\end{array}$ \\
\hline$D E N$ & $\begin{array}{c}-0.731 \\
(9.39)\end{array}$ & $\begin{array}{c}-0.498 \\
(2.54)\end{array}$ & $\begin{array}{r}-0.165 \\
(2.20)\end{array}$ & $\begin{array}{c}-0.269 \\
(1.67)\end{array}$ \\
\hline Schooling & $\begin{array}{r}0.044 \\
(25.05)\end{array}$ & $\begin{array}{c}0.023 \\
(3.44)\end{array}$ & $\begin{array}{r}0.040 \\
(19.37)\end{array}$ & $\begin{array}{c}0.032 \\
(5.70)\end{array}$ \\
\hline Exper & $\begin{array}{r}0.025 \\
(19.48)\end{array}$ & $\begin{array}{c}0.016 \\
(3.53)\end{array}$ & $\begin{array}{r}0.012 \\
(10.44)\end{array}$ & $\begin{array}{c}0.008 \\
(2.47)\end{array}$ \\
\hline Exper $^{2} / 100$ & $\begin{array}{l}-0.043 \\
(16.07)\end{array}$ & $\begin{array}{r}-0.021 \\
(2.39)\end{array}$ & $\begin{array}{c}-0.024 \\
(9.48)\end{array}$ & $\begin{array}{c}-0.014 \\
(2.09)\end{array}$ \\
\hline Tenure & $\begin{array}{r}0.018 \\
(13.23)\end{array}$ & $\begin{array}{c}0.013 \\
(2.57)\end{array}$ & $\begin{array}{r}0.025 \\
(15.63)\end{array}$ & $\begin{array}{c}0.023 \\
(5.12)\end{array}$ \\
\hline Tenure $^{2} / 100$ & $\begin{array}{c}-0.036 \\
(8.35)\end{array}$ & $\begin{array}{r}-0.032 \\
(1.95)\end{array}$ & $\begin{array}{c}-0.053 \\
(9.28)\end{array}$ & $\begin{array}{c}-0.054 \\
(3.59)\end{array}$ \\
\hline Union & $\begin{array}{c}0.074 \\
(8.18)\end{array}$ & $\begin{array}{r}0.077 \\
(2.34)\end{array}$ & $\begin{array}{c}0.033 \\
(3.16)\end{array}$ & $\begin{array}{c}0.070 \\
(2.72)\end{array}$ \\
\hline Married & $\begin{array}{r}0.093 \\
(10.04)\end{array}$ & $\begin{array}{c}0.027 \\
(0.86)\end{array}$ & $\begin{array}{c}0.012 \\
(1.51)\end{array}$ & $\begin{array}{r}-0.008 \\
(0.36)\end{array}$ \\
\hline Fulltime & $\begin{array}{c}0.117 \\
(8.34)\end{array}$ & $\begin{array}{c}0.201 \\
(4.32)\end{array}$ & $\begin{array}{r}0.079 \\
(8.71)\end{array}$ & $\begin{array}{c}0.077 \\
(2.52)\end{array}$ \\
\hline Large SMSA & $\begin{array}{c}0.083 \\
(9.96)\end{array}$ & $\begin{array}{c}0.100 \\
(3.03)\end{array}$ & $\begin{array}{r}0.096 \\
(11.18)\end{array}$ & $\begin{array}{c}0.110 \\
(4.41)\end{array}$ \\
\hline Firm size (4) & yes & yes & yes & yes \\
\hline Industry (13) & yes & yes & yes & yes \\
\hline Occupation (5) & yes & yes & yes & yes \\
\hline Region (8) & yes & yes & yes & yes \\
\hline$\overline{\mathrm{R}}^{2}$ & 0.526 & 0.455 & 0.474 & 0.494 \\
\hline $\mathrm{n}$ & 10,776 & 811 & 9,016 & 963 \\
\hline
\end{tabular}

$|t|$ in parentheses. Dependent variable is $\ln W$. All variables are defined in Table 1. Numbers in parentheses following firm size, industry, occupation, and region indicate number of dummy variables included in regression equations. 
$[\exp (\gamma)-1] 100$, where $\gamma$ is the coefficient on $D E N)$. Of course, entirely black IOR groups are not represented in our data. More realistically, we might ask how white and black wages are estimated to change as the racial composition of jobs for each group of workers moves toward equality (this is similar to the question asked by Bergmann (1971)). Mean DEN for our entire sample of workers is .098. For white males, an increase in $D E N$ from their current .083 to .098 percent is associated with a decrease in their wages by an estimated 1.1 percent $\left(\left[\exp \left(\gamma^{w}(.098-.083)\right)-\right.\right.$ 1] 100 , where $\gamma$ is the relevant coefficient on $D E N)$, whereas for black males a change in $D E N$ from their current .168 to .098 is associated with an estimated 3.5 percent wage gain $\left(\left[\exp \left(\gamma^{b}(.098-.168)\right)-1\right] 100\right)$.

The evidence for females indicates weaker and less significant relationships between wages and $D E N$ than those observed for males, although the qualitative results are similar. The estimated impact for white women of a change to job markets with average density is effectively zero, since their mean $D E N$ approximately equals the total sample mean. For black women, a change in $D E N$ from .198 to .098 is estimated to increase wages by 2.7 percent $\left(\left[\exp \left(\gamma^{b}(.098-.198)\right)-1\right] 100\right)$.

Table 3 provides evidence of differences in $D E N$ coefficients for each of the four demographic groups when the samples are segmented by age, location in the South, and schooling. We will refer to these findings subsequently as results are interpreted in Section IV. The negative effect of racial density on black wages is found to be restricted to young workers (ages 16-34), whereas negative density effects on white wages are large for both age groups (but somewhat larger for older whites). The youth sample (ages 16-23) results allow comparison with Ragan and Tremblay (1988), who utilized a sample of 15-23 year olds from the NLS. Although sample sizes are small, the substantial differences in results between those for the youth sample and those obtained for broader groups suggest that care must be exercised before generalizing youth results to the general population. For all four demographic groups, the negative effect of density on wages is larger for more highly schooled groups. For blacks, the density effect is much smaller for those with less than a high school degree; for whites, the negative effect of racial density increases with each level of schooling. Finally, for all except black females, the negative density effect is substantially larger among workers outside the South than for workers in the South, the difference being particularly large for black males. Note that the findings reported in Table 3 overlap to some extent. More highly schooled workers are more likely to be young and reside outside the South, and $D E N$ coefficients are most negative where blacks have low representation (this latter pattern suggests a nonlinear relationship between $\ln W$ and $D E N)$. 
Table 3

DEN Coefficients from Segmented Regressions by Age, Schooling, and Region, by Racial/Gender Group

\begin{tabular}{|c|c|c|c|c|}
\hline Group & $\begin{array}{l}\text { White } \\
\text { Males }\end{array}$ & $\begin{array}{l}\text { Black } \\
\text { Males }\end{array}$ & $\begin{array}{c}\text { White } \\
\text { Females }\end{array}$ & $\begin{array}{c}\text { Black } \\
\text { Females }\end{array}$ \\
\hline \multirow[t]{3}{*}{ Ages $35-64$} & -0.890 & -0.007 & -0.273 & 0.017 \\
\hline & $(7.98)$ & $(0.02)$ & $(2.50)$ & $(0.07)$ \\
\hline & {$[5,389]$} & [451] & {$[4,332]$} & [495] \\
\hline \multirow[t]{3}{*}{ Ages 16-34 } & -0.586 & -0.716 & -0.183 & -0.572 \\
\hline & $(5.42)$ & $(2.70)$ & $(1.78)$ & $(2.54)$ \\
\hline & {$[5,387]$} & [360] & {$[4,684]$} & [468] \\
\hline \multirow[t]{3}{*}{ Ages 16-23 } & -0.374 & -1.703 & 0.051 & -0.093 \\
\hline & $(2.37)$ & $(2.44)$ & $(0.33)$ & $(0.25)$ \\
\hline & {$[1,773]$} & [91] & {$[1,636]$} & {$[120]$} \\
\hline \multirow[t]{3}{*}{ Schooling $<12$} & -0.308 & -0.010 & -0.058 & 0.006 \\
\hline & $(2.18)$ & $(0.03)$ & $(0.39)$ & $(0.02)$ \\
\hline & {$[2,034]$} & [268] & {$[1,238]$} & [238] \\
\hline \multirow[t]{3}{*}{ Schooling $=12$} & -0.566 & -0.763 & -0.138 & -0.429 \\
\hline & $(4.65)$ & $(2.42)$ & $(1.29)$ & $(1.80)$ \\
\hline & {$[4,075]$} & [310] & {$[4,147]$} & [404] \\
\hline \multirow[t]{3}{*}{ Schooling $>12$} & -1.209 & -0.762 & -0.186 & -0.492 \\
\hline & $(7.91)$ & $(1.80)$ & (1.16) & (1.10) \\
\hline & {$[4,667]$} & [233] & {$[3,631]$} & [321] \\
\hline \multirow[t]{3}{*}{ Non-South } & -1.444 & -2.151 & -0.549 & -0.175 \\
\hline & $(10.20)$ & $(3.27)$ & $(4.32)$ & $(0.41)$ \\
\hline & {$[7,785]$} & [333] & {$[6,589]$} & [384] \\
\hline \multirow[t]{3}{*}{ South } & -0.544 & -0.320 & -0.255 & -0.515 \\
\hline & $(4.52)$ & $(1.41)$ & $(2.09)$ & $(2.09)$ \\
\hline & {$[2,991]$} & [478] & {$[2,427]$} & [579] \\
\hline
\end{tabular}

$|t|$ in parentheses. Sample sizes in brackets. Other included variables are Schooling, Exper and Exper ${ }^{2}$, Tenure and Tenure ${ }^{2}$, Union, Married, Fulltime, Large SMSA, and sets of dummies for firm size, industry, occupation, and region. The regression results for ages 16-23 facilitate comparison with Ragan and Tremblay (1988). 
The robustness of the wage-density relationship is probed in several ways. Wage equations with a correction for selectivity bias are estimated (details are available on request). Following criteria suggested by Nakamura and Nakamura (1990), coefficients on $D E N$ and adjusted $\mathrm{R}^{2} \mathrm{~s}$ are found to be highly similar with and without the selectivity adjustment. Thus, inferences based on previously presented results are unaffected by the selectivity bias. In further work not shown, we estimated weighted regressions with sample sizes of the IOR cells as weights. Again, results are highly similar to those presented in the paper.

We next examine the robustness of the density results, as well as attempt to infer the routes through which racial composition affects wages, by estimating density coefficients using twelve alternative specifications. Specifications differ by variables included and functional form of the wage-density relationship. To examine nonlinearities in the log wage-density relationship, the model is estimated in quadratic form, with $D E N$ and $D E N S Q$ as right-hand-side variables. ${ }^{6}$ Results from both functional forms are shown in Table 4. Line 1 contains results from models with only the racial composition variables included, line 2 results are for models adding all personal characteristics and firm size variables, line 3 adds industry dummies to line 2, line 4 adds occupation dummies to line 2 , line 5 adds regional and the SMSA dummies to line 2, and line 6 includes all variables.

The change in coefficients between lines 1 and 2 of Table 4 makes it evident that some of the simple correlation between wages and racial composition results from differences in personal characteristics correlated with $D E N$. The addition of industry (line 3) or region (line 5) dummies to the model has relatively little additional impact on $\gamma^{w}$ or $\gamma^{b}$. By contrast, addition of occupation dummies substantially decreases the estimated impact of $D E N$ (note the similarity of lines 4 and 6). Much of the simple correlation of wages with the racial composition of labor markets appears to result from differences in personal characteristics and broad occupational differences correlated with $D E N$. Jobs with higher proportions of black workers tend to have lower levels of wage-enhancing characteristics and to be in lower-paying occupational categories. The

6. The quadratic form has the undesirable property that $D E N$ is estimated to have positive effects on wages at very high density levels; however, these levels are well outside the observed value for most workers. A double log form performed similarly to the quadratic (in terms of inferences and goodness-of-fit), but it has the drawback that $\ln (D E N)$ is not defined at zero density. Although only a few of our cells have zero density, more disaggregated measures of density would have a substantial number of job cells with no black workers. 
Table 4

Racial Density Coefficients, by Specification and Racial/Gender Group

\begin{tabular}{|c|c|c|c|c|c|c|c|}
\hline Specification & $\gamma^{w}$ & $\gamma^{b}$ & $\gamma^{w}-\gamma^{b}$ & $\phi_{1}^{w}$ & $\phi_{2}^{w}$ & $\phi_{1}^{b}$ & $\phi_{2}^{b}$ \\
\hline \multicolumn{8}{|l|}{ Males } \\
\hline 1. Density only & $\begin{array}{l}-1.683 \\
(23.43)\end{array}$ & $\begin{array}{l}-1.582 \\
(10.69)\end{array}$ & $\begin{array}{c}-0.102 \\
(0.59)\end{array}$ & $\begin{array}{l}-2.363 \\
(13.39)\end{array}$ & $\begin{array}{r}2.077 \\
(4.22)\end{array}$ & $\begin{array}{c}-3.136 \\
(6.23)\end{array}$ & $\begin{array}{r}3.281 \\
(3.23)\end{array}$ \\
\hline $\begin{array}{l}\text { 2. Line (1) plus individual and firm char- } \\
\text { acteristics }\end{array}$ & $\begin{array}{l}-1.076 \\
(19.18)\end{array}$ & $\begin{array}{r}-1.099 \\
(8.58)\end{array}$ & $\begin{array}{c}0.023 \\
(0.17)\end{array}$ & $\begin{array}{l}-2.134 \\
(15.71)\end{array}$ & $\begin{array}{l}3.210 \\
(8.54)\end{array}$ & $\begin{array}{c}-2.831 \\
(6.66)\end{array}$ & $\begin{array}{r}3.631 \\
(4.27)\end{array}$ \\
\hline 3. Line (2) plus industry dummies & $\begin{array}{l}-1.086 \\
(19.00)\end{array}$ & $\begin{array}{c}-1.216 \\
(8.96)\end{array}$ & $\begin{array}{c}0.130 \\
(0.91)\end{array}$ & $\begin{array}{l}-2.155 \\
(15.66)\end{array}$ & $\begin{array}{r}3.169 \\
(8.54)\end{array}$ & $\begin{array}{r}-3.200 \\
(7.47)\end{array}$ & $\begin{array}{r}4.182 \\
(4.88)\end{array}$ \\
\hline 4. Line (2) plus occupation dummies & $\begin{array}{l}-0.727 \\
(12.23)\end{array}$ & $\begin{array}{c}-0.861 \\
(6.13)\end{array}$ & $\begin{array}{c}0.134 \\
(0.89)\end{array}$ & $\begin{array}{l}-1.758 \\
(12.71)\end{array}$ & $\begin{array}{l}3.065 \\
(8.25)\end{array}$ & $\begin{array}{c}-2.270 \\
(5.07)\end{array}$ & $\begin{array}{r}2.890 \\
(3.31)\end{array}$ \\
\hline $\begin{array}{l}\text { 5. Line (2) plus regional dummies and } \\
\text { large SMSA }\end{array}$ & $\begin{array}{l}-1.241 \\
(18.76)\end{array}$ & $\begin{array}{r}-0.840 \\
(5.54)\end{array}$ & $\begin{array}{c}-0.401 \\
(2.46)\end{array}$ & $\begin{array}{l}-2.480 \\
(16.61)\end{array}$ & $\begin{array}{l}3.529 \\
(9.24)\end{array}$ & $\begin{array}{r}-2.395 \\
(4.89)\end{array}$ & $\begin{array}{r}3.041 \\
(3.34)\end{array}$ \\
\hline $\begin{array}{l}\text { 6. Line (5) plus industry and occupation } \\
\text { dummies }\end{array}$ & $\begin{array}{c}-0.731 \\
(9.39)\end{array}$ & $\begin{array}{c}-0.498 \\
(2.54)\end{array}$ & $\begin{array}{r}-0.234 \\
(1.14)\end{array}$ & $\begin{array}{l}-1.878 \\
(10.88)\end{array}$ & $\begin{array}{r}2.917 \\
(7.44)\end{array}$ & $\begin{array}{c}-1.908 \\
(3.34)\end{array}$ & $\begin{array}{r}2.559 \\
(2.62)\end{array}$ \\
\hline
\end{tabular}




\section{Females}

1. Density only

$\begin{array}{ccccccc}-1.044 & -1.179 & 0.135 & -0.690 & -0.866 & -1.586 & 0.642 \\ (16.28) & (14.02) & (1.18) & (4.74) & (2.71) & (5.56) & (1.49) \\ -0.569 & -0.663 & 0.094 & -0.847 & 0.678 & -1.763 & 1.791 \\ (10.72) & (8.04) & (0.90) & (7.09) & (2.60) & (7.08) & (4.67) \\ -0.789 & -0.943 & 0.155 & -1.817 & 2.442 & -2.349 & 2.532 \\ (13.96) & (9.22) & (1.24) & (14.68) & (9.33) & (8.41) & (5.40) \\ -0.115 & -0.391 & 0.276 & -0.183 & 0.163 & -1.081 & 1.058 \\ (2.06) & (4.02) & (2.33) & (1.52) & (0.64) & (3.82) & (2.60) \\ -0.499 & -0.489 & -0.010 & -0.644 & 0.332 & -1.387 & 1.344 \\ (8.28) & (5.06) & (0.09) & (4.95) & (1.25) & (4.74) & (3.25) \\ -0.165 & -0.269 & 0.104 & -0.740 & 1.145 & -1.318 & 1.490 \\ (2.20) & (1.67) & (0.55) & (4.66) & (4.11) & (3.10) & (2.66)\end{array}$

$|t|$ in parentheses. Superscripts $w$ and $b$ represent white and black, respectively; $\gamma$ are coefficients on $D E N$; and $\phi_{1}$ and $\phi_{2}$ are coefficients on $D E N$ and $D E N S Q$, respectively. The term $\gamma^{w}-\gamma^{b}$ and its $t$-ratio are obtained from a stacked regression in which race is interacted with all explanatory variables. 
racial composition of labor markets continues to be significantly related to hourly earnings, however, even following control for the occupational, industrial, and regional structure.

Although wages for all demographic groups are found to decrease with respect to racial density, no conclusive evidence is found that the racial wage gap varies systematically with respect to racial composition. Racial differences in the DEN coefficients shown in Table $4\left(\gamma^{w}-\gamma^{b}\right)$ do not display a consistent pattern and are not statistically significant. Taking the point estimates in line 6 at face value, however, the results would imply that the male racial gap narrows and the female gap widens with density.

The quadratic specification with $D E N$ and $D E N S Q$ indicates that the relationship between $\ln W$ and racial density is nonlinear, with log wages decreasing with respect to $D E N$ at a decreasing rate. Such a pattern is evident for all demographic groups. The coefficients shown on line 6 of Table 4 imply that wages reach a minimum with respect to $D E N$ at density levels of $.32, .37, .32$, and .44 for white males, black males, white females, and black females, respectively. These density levels are very high relative to mean density among these groups $(.08, .17, .10$, and .20 , respectively). The quadratic results suggest that the marginal wage effect of racial density is small for workers in jobs with relatively high concentrations of black workers. ${ }^{7}$

We next decompose the racial wage gap into components that are explained, unexplained, and owing to differences in racial composition (see Equation 2). These results are presented in Table 5. Letting ${\overline{\ln W^{w}}}_{-}$ $\overline{\ln W^{b}}$ be the total racial logarithmic wage gap, the differential explained by racial differences in the $X^{\prime}$ s is $\Sigma \beta^{w}\left(\bar{X}^{w}-\bar{X}^{b}\right)$. The unexplained differential (a measure of discrimination) is $\left[\Sigma\left(\beta^{w}-\beta^{b}\right) \bar{X}^{b}+\left(\gamma^{w}-\right.\right.$ $\left.\gamma^{b}\right) \overline{D E N}^{b}$, representing differences by race in the wage structure. The term $\gamma^{w}\left(\overline{D E N}^{w}-\overline{D E N}^{b}\right)$ measures wage differences resulting from differences in $D E N$. As discussed in the next section, this third component may result in part from discrimination, and in part from quality differences (interpretation of $\gamma^{w}-\gamma^{b}$, included in the discrimination component, is not clear-cut).

As seen in Table 5, the unadjusted or total racial wage gap is .226 for males and .047 for females. Much of the wage gap is unexplained, re-

7. Letting $\phi_{1}$ and $\phi_{2}$ be the coefficients on DEN and DENSQ, respectively, the density levels at which wages are minimized are calculated by setting $\partial \ln W / \partial D E N=\phi_{1}+$ $2 \phi_{2} D E N=0$, and, solving for $D E N$ by $-\phi_{1} / 2 \phi_{2}$. Andrew Weiss has suggested that a minimum wage law (or other floor on wages) may lead both to a nonlinear density relationship and a weaker relationship in the South, since wages cannot fall in many jobs with high $D E N$ and low wages. 
sulting from differences in regression parameters, or associated with differences in $D E N$. Focusing first on line 4, over 40 percent of the male racial gap and over two-thirds of the female gap cannot be accounted for by differences in racial density or measured characteristics. Even after controlling in detail for measured characteristics and industry, occupation, and regional dummies, approximately a third of the male and female racial wage gap is associated with differences in the racial composition of labor markets. Addition of the racial density variable to a sparse specification sharply reduces estimates of discrimination (compare the unexplained gaps in lines 1 and 3), but unexplained gaps are reduced only moderately by the addition of $D E N$ when there exist detailed controls (compare lines 2 and 4). We of course have more confidence in the decomposition analysis for men than for women, since the small racial wage gap among women makes the decomposition highly sensitive to small changes in coefficients and means. ${ }^{8}$

In summary, the racial composition of jobs is found to be an important wage determinant for white and black workers, and differences in mean density between black and white workers helps account for a nontrivial portion of the racial wage gap. If wage differences attributable to racial composition are not the result of discrimination, then previous estimates of racial discrimination (the unexplained gap) have not been seriously biased, at least those from studies that have included detailed controls for industry, occupation, and region. On the other hand, the studies have ignored what appears to be an important determinant of white and black wage rates, at least some portion of which is likely to result from discrimination. We now turn to the question not addressed in our analysis thus far-why wages vary systematically with the racial composition of labor markets?

\section{Interpretation of Results and Theories of Labor Market Discrimination}

The wages of both white and black workers have been shown to decrease with respect to racial density, while the racial wage gap has not been found to vary systematically with density. Can these results tell us anything about the mechanism through which racial compo-

8. Inferences are broadly similar using a decomposition with black coefficient weights. For example, the estimated explained, unexplained, and composition gaps in line 4 for males are $0.053,0.131$, and 0.042 , respectively; in line 5 they are $0.023,0.117$, and 0.086 . As stated previously in the text, we believe the use of white weights is preferable since it should be closest to a "nondiscriminatory" wage structure. 
Table 5

Decomposition of Racial Wage Differentials, by Gender

\begin{tabular}{|c|c|c|c|c|}
\hline Specification & $\begin{array}{l}\text { Total Racial } \\
\text { Wage Gap }\end{array}$ & $\begin{array}{l}\text { Explained } \\
\text { Wage Gap }\end{array}$ & $\begin{array}{l}\text { Unexplained } \\
\text { Wage Gap }\end{array}$ & $\begin{array}{c}\text { Gap Due } \\
\text { to Racial } \\
\text { Composition }\end{array}$ \\
\hline \multicolumn{5}{|l|}{ Males } \\
\hline 1. All individual and firm characteristics & 0.226 & $\begin{array}{c}0.043 \\
(19.0 \%)\end{array}$ & $\begin{array}{l}0.183 \\
(81.0 \%)\end{array}$ & - \\
\hline $\begin{array}{l}\text { 2. Line (1) plus industry, occupation, and regional } \\
\text { controls }\end{array}$ & 0.226 & $\begin{array}{c}0.103 \\
(45.6 \%)\end{array}$ & $\begin{array}{l}0.123 \\
(54.4 \%)\end{array}$ & - \\
\hline 3. Line (1) plus $D E N$ & 0.226 & $\begin{array}{l}0.035 \\
(15.5 \%)\end{array}$ & $\begin{array}{l}0.103 \\
(45.6 \%)\end{array}$ & $\begin{array}{c}.088 \\
(38.9 \%)\end{array}$ \\
\hline 4. Line (2) plus $D E N$ & 0.226 & $\begin{array}{c}0.066 \\
(29.2 \%)\end{array}$ & $\begin{array}{l}0.098 \\
(43.4 \%)\end{array}$ & $\begin{array}{c}.062 \\
(27.4 \%)\end{array}$ \\
\hline 5. Line (2) plus $D E N$ and $D E N S Q$ & 0.226 & $\begin{array}{c}0.049 \\
(21.7 \%)\end{array}$ & $\begin{array}{l}0.104 \\
(46.0 \%)\end{array}$ & $\begin{array}{c}.073 \\
(32.3 \%)\end{array}$ \\
\hline
\end{tabular}


Females

1. All individual and firm characteristics

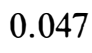

2. Line (1) plus industry, occupation, and regional

0.047

$$
\begin{gathered}
-0.039 \\
(-83.0 \%)
\end{gathered}
$$
controls

3. Line (1) plus $D E N$

0.009

$(19.1 \%)$

$-0.041$

$(-87.2 \%)$

0.047

0.001

$(2.1 \%)$

0.047

$-0.009$

$(-19.1 \%)$

0.086
$(183.0 \%)$
0.038
$(80.9 \%)$
0.038
$(80.9 \%)$
0.030
$(63.8 \%)$
0.038
$(80.9 \%)$

.050

(106.4\%)

.016

.018

(38.3\%)

See Equation (2) in text. The total racial wage gap is $\overline{\ln W^{w}}-\overline{\ln W^{b}}$. The explained wage gap is calculated by $\Sigma \beta^{w}\left(\bar{X}^{w}-\bar{X}^{b}\right)$. The unexplained wage gap is calculated by $\left[\Sigma\left(\beta^{w}-\beta^{b}\right) \bar{X}^{b}+\left(\gamma^{w}-\gamma^{b}\right) \overline{D E N^{b}}\right]$ in lines 3 and 4 and by $\left[\Sigma\left(\beta^{w}-\beta^{b}\right) \bar{X}^{b}+\left(\phi_{1}^{w}-\phi_{1}^{b}\right) \overline{D E N^{b}}+\left(\phi_{2}^{w}-\phi_{2}^{b}\right)\right.$ $\left.\overline{D E N S Q}^{b}\right]$ in line 5. The gap due to differences in the racial composition of IOR.cells is measured by $\gamma^{w}\left(\overline{D E N}^{w}-\overline{D E N}^{b}\right)$ in lines 3 and 4 and by $\phi_{1}^{w}\left(\overline{D E N}^{w}-\overline{D E N}^{b}\right)+\phi_{2}^{w}\left(\overline{D E N S Q}^{w}-\overline{D E N S Q}^{b}\right)$ in line 5 . The numbers in parentheses represent the percentage each component contributes to the total differential (these may not add up to 100 percent owing to rounding error). 
sition affects wages, or the sources of discrimination? Although our work does not provide a rigorous test of any specific theory of discrimination, the evidence does shed light on the plausibility of alternative theories. Among the most widely recognized theories or descriptions of labor market discrimination are taste models identifying the preferences of employers, employees, and consumers as sources of discrimination; models of statistical discrimination focusing on imperfect and costly information about worker productivities; and the "crowding" hypothesis, wherein groups of workers are restricted to particular job markets. ${ }^{9}$ These alternative models of discrimination may provide different predictions about the signs of the racial density coefficients in the white and black wage equations $\left(\gamma^{w}\right.$ and $\gamma^{b}$, respectively) and their difference $\left(\gamma^{w}-\gamma^{b}\right)$. A positive value for $\left(\gamma^{w}-\gamma^{b}\right)$ indicates that the racial wage gap widens with density. The evidence presented here indicates that $\gamma^{w}$ and $\gamma^{b}$ are negative, while $\left(\gamma^{w}-\gamma^{b}\right)$ is indeterminate and close to zero.

Taste models of employer discrimination predict that employers with a taste for discrimination are willing to pay a premium for white workers over equally productive black workers or, similarly, pay blacks less than equivalent whites to receive the same net "product." 10 As long as the number of discriminatory employers and size of the black workforce in the labor market are relatively small, there will be no wage differential. Rather, blacks will work for nondiscriminatory employers, while discriminatory employers will hire all whites. But as the relative size of the black labor force increases, employer discrimination will lead to a decrease in relative black wages and an increase in relative white wages. If employer discrimination were the major explanation for racial wage differences, the wage gap should widen as the density of black workers in a labor market increases. Yet our results show that white wages decrease with respect to density and that there is no significant relationship between the gap and racial composition. The empirical results provide no support for the employer taste model.

9. See Becker (1971) for a presentation of neoclassical taste models, Arrow (1973) and Phelps (1972) for development of early models of statistical discrimination, Bergmann (1971) for development of the crowding theory as applied to race, and Cain (1986) for a detailed survey and analysis of the discrimination literature.

10. We ignore the distinction between nepotism and discrimination models (Goldberg 1982). In the former, whites are paid more than their marginal products, whereas in the latter, blacks are paid less than their marginal products. If marginal products were approximated by the predicted wage from a regression, with racial density set to zero, a nepotism model would predict that white wages increase with respect to density, whereas the discrimination model would predict that black wages fall with density. If both nepotism and discrimination are at work, white wages should rise and black wages decline with density. Regardless, the racial gap should widen with density, and white wages should not decrease with density. 
Let us assume that employee discrimination is characterized by the preferences of some white employees not to work with blacks. White workers must receive a premium to work with blacks and, quite possibly, this premium increases with the proportion of black workers. ${ }^{11}$ If the number of prejudiced workers is small and there exist opportunities to work in segregated work environments, no wage differential will result. But as the number of prejudiced workers and the proportion of blacks in the workforce increase, a white premium is more likely. Black wages should be little affected by racial density if they are indifferent about the race of coworkers. Thus, employee discrimination leads to the prediction of higher white wages and a larger racial wage gap in labor markets with higher densities of black workers. No such evidence is found.

Consumer preferences with respect to race may also generate wage differentials. If the number of such consumers and the size of the black workforce are small no differential is likely. But if white consumer discrimination is widespread and segregation of blacks into invisible jobs is costly, white premiums and black penalties should increase, and the racial wage gap should widen, as the proportion of the workforce that is black increases. Again, our evidence lends no support to the consumer tastes model as an important force in wage determination. ${ }^{12}$

Although we find no evidence to support the taste models of discrimination, it must be pointed out that these are neither overly strong nor direct tests of the models. More fundamentally, most U.S. labor markets may have too few black workers for racial wage differentials associated with tastes to be evident. If there are sufficient numbers of nondiscriminatory employers, employees, and consumers, most black workers can be hired at prevailing wage rates with no black-white market differential. This being said, if employer, employee, and consumer tastes were the primary transmission mechanism for otherwise unexplained racial wage differentials, it is likely that we would observe a positive relationship of white wage rates and the racial gap with respect to the racial density of labor markets. We do not.

Statistical discrimination results when there is imperfect information about individual worker productivities. The well-known Aigner-Cain

11. Becker predicts a wage premium for workers in an integrated workplace regardless of the extent of integration, whereas Arrow models the size of the premium to be an increasing function of the proportion of workers of the opposite race. Ragan and Tremblay (1988, p. 124) provide a clear exposition on this point and attempt to distinguish empirically among these alternatives.

12. The racial density of $I O R$ cells will be at least weakly correlated with the racial makeup of a firm's customer base, making interpretation of $\gamma^{w}$ and $\gamma^{b}$ less straightforward. It is unlikely that such effects are substantial. 
model of statistical discrimination (see Cain 1986) assumes an equivalent distribution of abilities among white and black workers, but "indicator" characteristics (for example, years of schooling) are less reliable measures of productivity for blacks than for whites. In this case, there will be no average group discrimination; high ability whites will be paid more than high ability blacks, while low ability whites will be paid less than low ability blacks. There is no obvious prediction about a relationship between white and black wages and the racial composition of labor markets, unless it is assumed that white and black workers must be treated similarly within job markets. In that case, predominately black workplaces should exhibit lower wage dispersion and a structure of earnings in which the returns associated with indicator variables are lower than in predominately white workplaces, but average wages should be similar (in other words, smaller slope coefficients but a larger intercept).

Alternative models of statistical discrimination can be developed, although it is unlikely that any of these could be the primary determinant of the wage-density relationship. For example, note that employers observe the race of applicants/employees and believe it to be correlated with productivity. Because the number of black applicants and workers is substantially lower than the number of whites, most employers observe a higher relative dispersion of productivities among black than among white employees. Stated alternatively, the small sample sizes of black employees make it more difficult for employers to predict accurately black worker productivities. As the relative size of the black workforce increases, uncertainty about worker productivities should decrease. Assuming risk averse employers (unlike Aigner and Cain), black wages thus should increase as black density increases (in other words, as uncertainty decreases), while white wage rates should be largely unaffected. The racial wage gap therefore will be smaller in high density labor markets. Again, direct support is not found for this version of statistical discrimination, since black wages decrease with respect to racial density and the racial wage gap does not vary systematically with density. ${ }^{13}$ Consistent with this model of statistical discrimination, however, is the finding that density has its most negative effect where there are relatively fewer blacks - outside the South and among highly schooled workers. And evidence indicates that the negative wage-density relationship is substantial for young but not older black workers, consistent with the notion that as workers and employers increase contact with each other, productivity is

13. Whatley (1990) presents a statistical discrimination model relying on similar arguments and provides historical evidence based on the records of companies in Atlanta and Cincinnati during 1914-18. 
revealed and uncertainty plays less of a role (or as expressed below, communication costs are reduced).

Implications from Lang's (1986) "language" model of discrimination may be similar to those presented above for the uncertainty hypothesis. Following Lang, blacks and whites display different language and communication patterns; minority workers who do not acquire majority language patterns are penalized in the labor market to compensate for the higher communication costs facing employers. A high density of black workers may signify greater contact between blacks and whites and a larger accumulated stock of communication capital. In this case, blacks should fare better in job markets with large numbers of black workers (and employers). On the other hand, it could be argued that blacks who do not acquire majority language patterns may be crowded into job markets with high densities of black workers and high communication costs between white and black workers and with employers. Blacks who acquire majority language patterns receive a return on these skills by being able to acquire jobs in predominately white and noncrowded labor markets. ${ }^{14}$ As discussed below, our statistical results are broadly consistent with the crowding model.

Crowding models of the labor market have been applied most frequently as an explanation for the gender wage gap and occupational differences in employment. Crowding is not so much a theory of discrimination as it is an outcome through which discrimination is manifest and in turn affects the wage structure. As applied to race, the crowding models would emphasize historical and discriminatory forces that have limited the mobility of black workers into some job markets, while crowding them into others (Higgs 1977, Whatley 1990). Consistent with the hypothesis of racial crowding (as well as other explanations) is the finding that there are substantial differences among blacks in desired and actual occupational attainment (Gill 1989).

Crowding should cause an increase in labor supply and depress equilibrium wages for both white and black workers in crowded job markets open to blacks, while having no predictable effect on the racial wage gap. Our results are largely consistent with the crowding model, since both white and black wage rates vary inversely with racial density. But there are unanswered questions. First, why would white workers not facing discriminatory barriers to other job markets remain where wages are lower? It is likely, therefore, that white workers who remain in racially crowded labor markets are on average less able or mobile than white counterparts in jobs with low concentrations of black workers. Second,

14. For evidence that language proficiency plays an important role in the earnings of Hispanics, see McManus, Gould, and Welch (1983). 
is the racial crowding explanation for lower wages (in other words, an increased labor supply) plausible, given relatively low IOR-cell racial densities even in jobs held by black workers? Admittedly, we would find the crowding explanation more compelling were we to observe negative wage effects primarily at high racial density levels (instead, white and black wages decrease at a decreasing rate with respect to density). Our $I O R$ cells aggregate across heterogeneous job markets, however, so that as $D E N$ increases, even at relatively low levels, we are likely to be capturing an increasing number of predominately black (in other words, crowded) jobs.

Finally, if crowding is the primary explanation for the wage-density relationship, we expect coefficients on $D E N$ to be most negative among black workers for whom an a priori expectation of racial crowding is strong. Earlier, we provided estimates in which $D E N$ coefficients were allowed to vary with respect to age, schooling, and region. It was found that the negative effects of racial composition on black workers were restricted to the young, males in the non-South, and those with at least a high school degree. These are not the groups of black workers for whom racial crowding should be most severe. Older black workers have faced greater employment barriers than have younger black workers. Young low-skill blacks are likely to be relocated to crowded jobs, but negative density effects are smallest for blacks with low schooling. And certainly crowding should be more severe in the South, where there is a higher proportion of black workers and where discrimination is believed to be highest (unexplained racial wage gaps are larger in the South). Yet the effects of racial density are smaller in the South than the non-South. For all these reasons, the crowding hypothesis does not appear to be an entirely adequate explanation for the wage-density relationship.

Although the wage-density relationship reflects the net outcome of many simultaneous forces, we believe results reported in this paper are consistent with a quality sorting explanation. There is likely to exist worker and employer sorting based on differences in job quality and unmeasured worker quality between jobs with high and low racial densities. That is, racial composition variables will be correlated with unobserved worker and job quality measures. The fact that measurable wageenhancing characteristics are lower in high density markets lends support to this hypothesis, assuming that measurable and unmeasurable labor quality factors are positively correlated.

For example, assume that jobs sort (in other words, match employers and workers) on observed and unobserved quality. If blacks have less unobserved quality owing, say, to less human capital attached to measured years of schooling and potential experience, then jobs requiring less skill will have relatively higher concentrations of black workers. 
Moreover, both whites and blacks will be less productive (and paid less) in high density jobs, while being more productive in low density jobs. Although the quality sorting explanation is consistent with our findings, this hypothesis is not tested explicitly by our work..$^{15}$ Our finding of more substantial racial density effects among more highly schooled workers, coupled with O'Neill's (1990) finding that the racial gap in achievement test scores increases with schooling level, lends credence to the thesis that quality sorting is an important part of the explanation for a wagedensity relationship.

The quality sorting explanation is not inconsistent with crowding (and other) models of discrimination. Past discrimination and differences in premarket skills that black and white workers traditionally brought to the labor market could have led to current labor market equilibria in which racial densities vary substantially across jobs. Markets with historically large concentrations of black workers are more likely to have settled into equilibria with lower observed and unobserved skill requirements (Akerlof 1976). The racial composition of jobs then has become a proxy for worker quality. Moreover, antidiscrimination laws and concerns about worker morale make it difficult to maintain racial wage differences within IOR cells, but do relatively little to prevent racial wage differences across job markets. Thus, high density job markets wherein black workers receive low wages must also pay low wages to whites employed in those markets. Over time, selective hiring and sorting lead to equilibria in which we observe lower quality whites and blacks in high density markets and higher quality workers in low density markets.

It is worth noting that interpretation of $\gamma$ will differ for black and white workers if this description of the labor market is accurate. For whites, $\gamma^{w}$ reflects the equilibrium "price" attached to omitted worker quality differences measured by $D E N$. For black workers $\gamma^{b}$ is a "price" for both quality and discrimination, since differences in $D E N$ reflect not only quality differences, but also racial crowding and other forms of past and present discriminatory behavior associated with racial composition. By

15. A longitudinal model examining wage changes of workers moving from low to high density markets (or vice-versa) could provide more direct evidence of unobserved quality differences. Besides requiring longitudinal data on individual workers, interpretation of such a model is not straightforward because of measurement error in change variables and the possibility that job change is endogenous. Preliminary work along these lines by Hirsch and Dave Macpherson supports the quality sorting explanation. We have also ignored what we consider the unlikely possibility that the wage-density relationship is the result of disequilibrium. That is, if blacks are less mobile owing to lower abilities and wealth, declining sectors will tend to have lower wages and a higher density of black workers. Such a thesis could be tested directly through the use of data on employment growth within IOR cells. 
this interpretation, $D E N$ may be regarded as a quality-related characteristic for white workers, whereas for black workers neither $D E N$ nor $\gamma^{b}$ have a clear a priori interpretation.

\section{Conclusion}

In this paper, we have shown that the racial composition of labor markets is an important determinant of wage rates. The wages of both white and black workers decrease with respect to racial density, measured by the ratio of black to the sum of white and black workers within industry-occupation-region cells. Evidence of a wage-density relationship is particularly clear-cut for males.

Although we have documented an important regularity in the U.S. labor market, the explanation for this relationship is not clear. Our evidence does not appear to be consistent with either taste models of discrimination or most models of statistical discrimination. The results are consistent with the hypothesis of quality sorting and partially consistent with theories of racial crowding and language discrimination. But our evidence does not allow us to distinguish conclusively between these alternative, although not mutually exclusive, views of the labor market. Whatever the explanation, the racial composition of labor markets appears to be an important factor in determining wage rates for white and black workers. It is hoped that future research can examine further this relationship with new sets of data and alternative racial composition measures, and can identify more precisely the routes through which racial composition and wage rates are related.

\section{References}

Akerlof, George. 1976. "The Economics of Caste and the Rat Race and Other Woeful Tales." Quarterly Journal of Economics 90(4):599-617.

Arrow, Kenneth. 1973. "The Theory of Discrimination." In Discrimination in Labor Markets, ed. Orley Ashenfelter and Albert Rees, 3-33. Princeton: Princeton University Press.

Becker, Gary S. 1971. The Economics of Discrimination, 2nd ed. Chicago: University of Chicago (original ed., 1957).

Bergmann, Barbara R. 1971. "The Effect on White Incomes of Discrimination in Employment." Journal of Political Economy 79(2):294-313.

Brown, Charles, and James Medoff. 1989. "The Employer Size-Wage Effect." Journal of Political Economy 97(5):1027-59.

Cain, Glen G. 1986. "The Economic Analysis of Labor Market Discrimination: 
A Survey." In Handbook of Labor Economics, Vol. 1, ed. Orley Ashenfelter and Richard Layard, 693-785. Amsterdam: North-Holland.

Chiswick, Barry R. 1973. "Racial Discrimination in the Labor Market: A Test of Alternative Hypotheses." Journal of Political Economy 81(6):1330-52.

Dickens, William T., and Lawrence F. Katz. 1987. "Inter-Industry Wage Differences and Industry Characteristics.' In Unemployment and the Structure of Labor Markets, ed. Kevin Lang and Jonathan S. Leonard, 48-89. New York: Basil Blackwell.

Gill, Andrew M. 1989. "The Role of Discrimination in Determining Occupational Structure." Industrial and Labor Relations Review 42(4):610-23.

Giles, David E. A. 1982. "The Interpretation of Dummy Variables in Semilogarithmic Equations: Unbiased Estimation." Economics Letters 10:77-79.

Goldberg, Matthew S. 1982. "Discrimination, Nepotism, and Long-Run Wage Differentials." Quarterly Journal of Economics 97(2):307-19.

Higgs, Robert. 1977. Competition and Coercion: Blacks in the American Economy, 1865-1914. Cambridge: Cambridge University Press.

Krueger, Alan B., and Lawrence H. Summers. 1987. "Reflections on the Inter-Industry Wage Structure." In Unemployment and the Structure of Labor Markets, ed. Kevin Lang and Jonathan S. Leonard. New York: Basil Blackwell, 17-47.

Lang, Kevin. 1986, “A Language Theory of Discrimination.'” Quarterly Journal of Economics 101(2):363-82.

McManus, Walter, William Gould, and Finis Welch. 1983. "Earnings of Hispanic Men: The Role of English Language Proficiency." Journal of Labor Economics 1(2):101-30.

Nakamura, Alice, and Masao Nakamura. 1990. "Selection Bias: More than a Female Phenomenon.' In Advances in Econometrics and Modelling, ed. Baldev Raj, 143-58. Dordrecht: Kluwer Academic Publishers.

Neumark, David. 1988. "Employers' Discriminatory Behavior and the Estimation of Wage Discrimination." Journal of Human Resources 23(3):279-95.

Oaxaca, Ronald. 1973. "Male-Female Wage Differentials in Urban Labor Markets.' International Economic Review 14(3):693-709.

O'Neill, June. 1990. "The Role of Human Capital in Earnings Differences Between Black and White Men.' Journal of Economic Perspectives 4(4):25-45.

Phelps, Edmund S. 1972. "The Statistical Theory of Racism and Sexism." American Economic Review 62(4):659-61.

Ragan, James F., Jr., and Carol Horton Tremblay. 1988. "Testing for Employee Discrimination by Race and Sex.' Journal of Human Resources 23(1):123-37.

Reich, Michael. 1978. "Who Benefits from Racism? The Distribution Among Whites of Gains and Losses from Racial Inequality.' Journal of Human Resources 13(4):524-44. 
Sorensen, Elaine. 1989. "Measuring the Effect of Occupational Sex and Race Composition on Earnings." In Pay Equity: Empirical Inquiries, ed. R. T. Michael, H. I. Hartmann, and B. O'Farrell, 49-69. Washington, DC: National Academy Press.

U.S. Department of Commerce. Bureau of the Census. 1984. 1980 Census of the Population, Characteristics of the Population, United States Summary, Vol. 1. Washington: GPO.

1985. Current Population Survey, May 1983: Pension and Retirement

Plan Coverage. ICPSR 8335. Ann Arbor, Mich.: Inter-university Consortium for Political and Social Research.

Whatley, Warren C. 1990. "Getting a Foot in the Door: 'Learning,' State Dependence, and the Racial Integration of Firms." Journal of Economic History 50(1):43-66. 